\title{
On Christianity in the Indian Malabar Coast and on the arrival of the Portuguese in a Syriac document from 1504
}

Taufīlos Ğōrğ Șalība, the bishop of the Mountains of Lebanon diocese of the Syriac Orthodox Church of Antioch, in his account of a pastoral visit of the Church's current patriarch, Mar Ig̉natiyyos Zakka I 'İwāṣ in India (from February, 2 to March, 24, 1982), called that Church "the Pearl of Antioch." The author was a member of the patriarchal delegation and his account was published on the $50^{\text {th }}$ anniversary of patriarch's Mar Ig்națiyyos Elias III Šākir's sudden death in India. ${ }^{1}$

The fact that there is such a very small number of works in the Polish language on the beginnings of Christianity in India and its development until the $15^{\text {th }}$ century gives rise to many questions, not to mention that an average Pole is not even aware of the fact of the existence of a Christian Church in

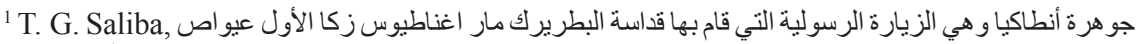
The Pearl of Antioch - an apostolic visit paid by His Holiness, Patriarch Mar Ignațiyyos Zakka I 'Iwās to the Syriac Church of Antioch in India, Damascus 1982, pp. 192 (after issues 14, 15 and 16 of the Patriarchal Magazine, Damascus). Patriarch Mar Ignațiyyos Elias III Šākir and the accompanying party left for India on the 28 February 1931 from the Iraqi port of Basra aboard the ship "Warsaw." They reached the port of Karachi on Thursday, the 5 March. The next day they boarded a train for Delhi, where they arrived on the 8 March. On Thursday (the $12 \mathrm{March}$ ) they set out on a 2-day long train journey to Madras, and after a week-long stay in this city, on Friday (the 21 st of March) they headed for Malabar. After an almost year-long stay in India the Patriarch died of heart attack on February 13, 1932 in the town of Manjinikkara, near the city of Omalloo/ $\mathrm{u} / \mathrm{r}$ and was buried next to the old St. Stephen church. The Mar Ignatịyos church was later built above his mausoleum. Currently both churches are situated within the premises of a monastery. Mar Iġnațiyyos Elias III Šākir, the $119^{\text {th }}$ patriarch of Antioch, counting from St. Peter, was the first head of the Church of Antioch to have been buried in India. His mausoleum is a destination of annual pilgrimages on February, $13^{\text {th }}$ which is the date of his death.
} 
India other than the Roman Catholic one. It is also a thought provoking fact that the two visits of the Polish Pope, the blessed John Paul II, in India (in 1986 and 1999) raised no interest at all of Polish historians, theological departments or media in the fascinating history of Christianity in the Indian subcontinent and in other distant countries of Asia. Few, scattered and in most cases very incomplete descriptions in the Polish language are mostly translations from other European languages and they could hardly form a basis for a panorama of the Christianity in that region. At the same time, one can easily find tens of book titles on the subject in the English language, which is obvious, but also in German, French, Latin, Arabic and Malayalam. The earliest of them date back probably to the $16^{\text {th }}$ century, but new books of this kind have been appearing almost incessantly from the early $19^{\text {th }}$ century to date. That is why the initiative to organize this conference in Cracow by Rev. Professor Krzysztof Kościelniak deserves appreciation. One may hope that this pioneering project will break the stereotypes, and result in further meetings of scholars promoting a broader view on Christianity and its richness in a spirit of true partnership. Nowadays, in the times so very difficult for the Christians of the East the knowledge on their history and contribution to our civilization should be spread as wide as possible, which should be accompanied with manifestation of understanding and respect for the centuries-long tradition as well as solidarity and support for their struggle to survive.

It is undeniable that Christianity initially reached Malabar in India, China and other parts of Central Asia and the Far East owing to Assyrian (Syriac) missionaries from Mesopotamia or by travelers from the neighboring regions, who crossed Mesopotamia or traveled along the famous Silk Road to get to these distant lands. This very early presence of Christians in India is documented with numerous confirmed accounts referring to St. Tomas and with material monuments among which the two copper tablets (one of them dated back to the $3^{\text {rd }}$ or $4^{\text {th }}$ century, while the $2^{\text {nd }}$ one to the $8^{\text {th }}$ century) are the most important ones. The text engraved on them includes the names of Mesopotamian shepherds and Christian notables who arrived to India in the $4^{\text {th }}, 8^{\text {th }}$ and $9^{\text {th }}$ centuries and mentions privileges granted to them in the local caste system. ${ }^{2}$ Five antique granite crosses have been also preserved as well as the names of successive hierarchs originating from Mesopotamia, although it is difficult to speak about the continuity of contacts.

The name of the first bishop of India, after St. Tomas, mentioned in historic sources, was Dada or David. He sailed to Malabar around the year 295 from

\footnotetext{
${ }^{2}$ Rev. H. Gundert, Translation and Analysis of the Ancient Documents Engraved on Copper In Possession of the Syrian Christians and Jews of Malabar, "Madras Journal of Literature and Science", edited by the Committee of the Madras Literary and Auxiliary Royal Asiatic Society, June 1844 no. 30, pp. 115-146.
} 
the port city of Basra in modern Iraq, which was an Episcopal see as early as in 225, just like Bēt Qațāye (the state of Qatar which in works by Syriac writers extended also over the present day Oman) and Bēt Lāpāt (GundēŠāpūr in Persian Khuzestan). ${ }^{3}$ These and other cities were located along the sea route leading from Mesopotamia to India and known since the ancient times. These urban centers, currently with no Christian population at all, were locations of monasteries populated with hundreds of monks. It is also known that the Christians of Malabar were under the jurisdiction of Antioch, chronologically the second apostolic see and the secondary see, Seleucia-Ctesiphon, was established following the 3rd Ecumenical Council. Nevertheless, trends aiming at decentralization and autonomy appeared in the church in India in some periods. Here, it must be noted that these trends were in a way forced by the changing geopolitical situation, both in the Middle East and in India itself, mainly due to the Arab Muslims expansion in the $11^{\text {th }}$ century in this country, and later on also due to the Turkish and Afghan sultanates in the $13^{\text {th }}$ up to $15^{\text {th }}$ century. On the other hand we know that Malabar Christians sometimes had to settle for direct contacts with the Church of the East in Persia, not only due to its geographical closeness and historical ties with the region but also because the ambitions of the church hierarchs, to gain independence from the headquarters of Antiochia or Seleucia-Ctesiphon, were often supported by the political authorities of Persia. Disregarding the few attempts to establish in India Churches of the western type undertaken since the end o the $13^{\text {th }}$ century, ${ }^{4}$ it can be said with certainty that

${ }^{3}$ See A. Mingana, The Early Spread of Christianity in India (in Arabic translation by Ğirğis Fathalla: فاتحة انتشار المسيحية في الهند, Stokholm: Zahrira 1999, pp. 10-12, 83). Further in the book A. Mingana included an extensive note on the crosses and tablets. In Syriac sources an expression "island bishops" is often found; it refers to the islands in the Indian Ocean and the Persian Gulf such as Socotra, Quatar, Bahrain and other. For instance in Quatar in 676 a local synod was held attended by 6 bishops, including one archbishop, were present. The synod was chaired by Gīwargis, the patriarch of the (Assyrian) Church of the East.

${ }^{4}$ Names, dates and other data on the Roman Catholic Church envoys as well as on their activity can be found in numerous publications, e.g., in: S. H. Moffet, A History of Christianity In India, vol. 1, Beginnings to 1500, Orbis Books, Maryknoll, $7^{\text {th }}$ ed., New York 2009, pp. 498-503; Ch. Baumer, The Church of the East. An Illustrated History of Assyrian Church, I. B. Tauris, $2^{\text {nd }}$ ed., London-New York 2008, pp. 235-239. For the needs of this paper one should mention John of Montecorvino, a priest sent by Pope Nicholas IV in 1291 to China. He stopped off in India for 13 months where he visited the grave of St. Tomas and was said to have baptized around 100 people. His companion, the Dominican, Nicholas of Pistoia died in Milappur and was buried in the local Syriac St. Thomas' church. John of Montecorvino was later nominated the Archbishop of China, and India was included under his jurisdiction. In turn in 1328 the Pope appointed Dominican Jordanus the bishop of the port city of Kollam, providing him with a letter addressed to the leaders of St. Thomas Christian community including a demand to recognize the primacy of Rome. In his "Mirabilia" report he wrote: "In this part of India (from Karachi to Malabar) lives a dispersed people calling themselves Christians, but Christians they are not: they have not been granted the blessing of baptism and they know no true faith, and apart from that they believe 
before the arrival of the Portuguese Malabar Christians had been fully aware of their affiliation with the above-named sees. Their way of practicing of the faith, preserved in numerous descriptions, had nothing to do with the Greek and Roman tradition. In daily life they spoke their local languages or dialects but for liturgy they used only Syriac. As early as in the $5^{\text {th }}$ century some of their intellectuals studied in famous Mesopotamian centers of scholarship and took an active part in the translation of Greek writings into the Syriac language. One must also remember that a clear separation between the jurisdictions of individual apostolic sees stemmed directly from certain canons of the First and Second Ecumenical Councils (of Nice in 325, and Constantinople in 381), ${ }^{5}$ which however were accepted only by some Churches.

Some sources mention that before the arrival of the Portuguese Christians probably accounted for almost half of the population of the coastal cities of Malabar. They were well organized and fairly well educated and lived in conflict with their Muslim neighbors. It may be presumed that like elsewhere, the conflict with the Muslims had both ideological and political background and was also a conflict of ambitions.

\section{"The first brothers" from the West}

The Portuguese were the first Europeans to reach India by sea in an organized manner. They arrived there 6 years after the discovery of America by Christopher Columbus. Based on historical sources it may be presumed that the initial intention of the Portuguese fleet organized with the blessing of King Emmanuel I and lead by Vasco da Gama, was not to make competitive "discoveries" but to bring from India pepper, cinnamon and cloves, spices highly valued in Europe. However, soon colonial ambitions and prestigious considerations of the sea power took over; Portugal, Spain and other European kingdoms tried to consolidate their efforts in fear of dangerous Islamic regimes of that time such as the Mamluks in Egypt or the Ottoman Turks. At the same time the countries engaged into large-scale proselytism, which they practiced in a premeditated manner among

that St. Thomas is Christ." Almost 20 years later the Franciscan bishop John of Marignola, who spent seven months in Kollam, noted that the "Nestorians" hold monopoly over the plantations of pepper and run the weights and measures office, which was in line with the privileges recorded on the aforementioned copper tablets. For more on these and other missionaries see: G. M. Rae, The Syrian Church in India, W. Blackwood, [no place of publication] 1892. Newer edition with a great number of printing errors: General-Books.net 2009.

${ }^{5}$ Rev. A. Baron, Rev. H. Pietras SJ, Dokumenty soborów powszechnych, vol. 1, WAM, Cracow 2009. Canon 6 of the Nice Council (in the Polish translation, p. 31) and canon 2 of the Constantinople Council (in the Polish translation, pp. 72-73). "Bishops of the Orient deal only with the Orient", "Bishops should not give holy orders without a special invitation nor should they fulfill other functions of their office outside of the area of their dioceses." 
the Christians aggregated around other apostolic sees and in the first stage of the European expansion it was difficult to see clearly which of these tasks was a priority. In order to prevent a potential conflict between Portugal and Spain, sea powers peacefully rivaling at that time, Pope Alexander VI entrusted the former power with the Latinization of the eastern part of the contemporary world, while the latter received the task to Latinize the western part. ${ }^{6}$

The Portuguese fleet of four ships reached the Indian port of Calicut in May of 1489 , but the visitors were not granted a permission to establish a factory in this location as originally planned.

What Vasco da Gama was unable to achieve was achieved a year later by another Portuguese sailor, Pedro Alvares Cabral. His thirteen ships strong fleet had over one thousand people aboard. The news about numerous Christian communities in Malabar was a great encouragement for this voyage. It turned out that the main source of the information was to be a Jewish merchant baptized by the Portuguese during the first expedition. They had given him the name Gaspar da Gama (Vasco da Gama himself was his godfather) and brought him to Portugal. His parents supposedly originated from Poznań but moved to Alexandria, Egypt as a result of persecution. Gaspar was born there, and when he grew up he took to trading with India. During an audience at King's Emmanuel I court he described the Christians in India as potential allies for the Portuguese but he certainly overrated their numbers and military potential. Still, his accounts must have been considered trustworthy if he served as a guide for both P. A. Cabral's expedition and during Vasco da Gama's second voyage. ${ }^{7}$

P. A. Cabral managed to negotiate with Samudri, the Raja of Calicut his consent for a group of Portuguese merchants to stay in the city. However, the agreement did not last long. After Cabral's departure from Malabar, Raja had all the European visitors killed. When the news about their death reached Portugal, the kingdom organized another expedition. In 1502 twenty ships commanded by Vasco da Gama in the rank of admiral left their home port. The Portuguese managed to seize both the city of Calicut and the city of Cochin. Trade agreements were signed with the Raja of the latter and with rajas of other cities on the west coast of South India.

${ }^{6}$ H. Tüchle, C. A. Bouman, Historia Kościoła, vol. 3, PAX, Warsaw 1986, p. 9. Both the title of this five-volume work and certain statements they include (such as "The Church has now reached out beyond the borders of the West" (ibid., p. 8) are misleading. In both cases the authors refer to the Roman Catholic Church.

${ }^{7}$ Extensive information on this is provided by S. Subrahmanyam, The Career and Legend of Vasco da Gama, Cambridge University Press, USA, pp. 145-163, who calls these persecutions of Jews in Poznan (at the end of the $15^{\text {th }}$ c.) "pogroms." According to Gaspar the numbers of Christian men able to carry the weapons in India was allegedly 212 thousand, including 74 thousand soldiers and cavalrymen and over 2100 war elephants. These rather unrealistic numbers were later supposedly spread among the Catholic kings in Europe by King Emmanuel I. 
All the available sources clearly point out to initial euphoria of the local Christians on meeting the European brothers in faith, who had been unknown to them before. P. A. Cabral befriended a Malabar priest named Yausef. Their friendship encouraged Yausef to accompany Cabral on the return trip to Europe. He was said to have visited Lisbon, Rome and Venice, and based on the information and observations he shared with his hosts a book entitled A journey of Yausef of India was allegedly published in $1507 .{ }^{8} \mathrm{He}$ even met the Pope, the earlier mentioned Alexander VI when in Rome. Asked by the Pope by what right the Nestorian patriarch exercised his jurisdiction over the Church of Malabar, he replied: "The one who was in charge of the Church in Antioch was St. Peter, who appointed his successor before leaving for Rome. The current patriarch is his next successor."

In 1503, having received a warning that Muslims (in literature referred to as the "Moors", "Saracens" or "Mohammedans") commanded by the Raja of Calicut plan to attack the Portuguese and their ally, the Raja of Cochin, the local Christians sent envoys to Vasco da Gama carrying the emblem of their unattained state in hope to find an ally in him. Reportedly the brave Portuguese sailor was given the scepter of a Christian king named or nicknamed Beliarte ${ }^{10}$ defeated by Muslims. However da Gama who saw them only as heretics treated this gesture as a sign of allegiance. If we are to believe the account provided by C. Buchanan, the following words were said during this meeting: To the envoy's statement that Christians have over one hundred churches (sic!) in Malabar, Vasco da Gama replied: "They shall belong to the Pope"! Hearing this, they asked: "Who is the Pope? We have not heard about him! No matter what your Christianity is, we derive from the place where Christ's followers

${ }^{8}$ The book was probably written in Latin and for this reason it cannot be found on the list of the first Syriac books printed in Europe in movable typeface. M. Abdalla, O drukarstwie w językach arabskim i syriackim i jego pionierach w XVI wieku. Paper delivered at the $8^{\text {th }}$ Conference of Polish Arabists, Department of Arabic and Islamic Studies, Faculty of Oriental Studies, University of Warsaw, 8-10 May 2009. G. M. Rae, The Syrian Church in India, op. cit., p. 94, maintains that P. A. Cabral brought "two Syrian brothers" from India to Portugal.

${ }^{9}$ This is stressed by Mar Severios Ya'qūb Tūma, تاريخ الكنيسة السريانية الهندية History of the Syriac Church in India, Beirut 1951, p. 41, referring to works by two authors: Th. Whitehouse, Lingerings of Light in a Dark Land: Being Researches into the Past History and Present Conditions of the Syrian Church in Malabar, London 1873, p. 81-82 and E. M. Philip, The Indian Church of St Thomas, Kottayam 1950, p. 136. St. Peter is the first patriarch of both the "Nestorian" and "Jacobite" Churches.

${ }^{10}$ Rev. Hugh Pearson, M.A. (of St John's College, Oxford), Rev. Claudius Buchanan. D.D., in some parts abridged and enlarged from dr. Buchanan's Christian Researches in Asia, published by the American Tract Society, New York [year of publication unknown], p. 305; G. M. Rae, The Syrian Church in India, op. cit., p. 77; S. Subrahmanyam, The Career and Legend of Vasco da Gama, op. cit., p. 94, doubts that Malabar Christians had such ambitions. He presumes that this alleged king could have been a bishop, archdeacon or a famous merchant. 
were called Christians for the first time."11 This account confirms the above mentioned words of Yausef on the affiliation of the Church of Malabar to the Antioch see, which is strongly emphasized by Mar Severios Ya'qūb Tūma.

As a token of gratitude for the liberation of Cochin Portugal received the land on which a castle called the Emmanuel's Castle was built in the years 1504-1505 and where the first Roman Catholic church of St. Francis was erected. The Portuguese eventually "cast anchor" in India for good only after Vasco da Gama's third expedition in 1524. This time he was sent there by King John III, Emmanuel's I successor. Vasco da Gama replaced the former viceroy of Portugal in India and considerably strengthened his country's influences in the region. However, he died in this very year and was buried in the abovementioned church. His remains were moved to Portugal only fifteen years later.

Before the Portuguese came to India the Church of Malabar had still had contacts with the Mesopotamian homeland. Information referring to this fact can be found in the below document in the Syriac language. ${ }^{12}$ Its content reflects the joy of the local Syriac Christians on the arrival of the Portuguese. However, later the relations with the visitors deteriorated, which gave rise to a great deal of bad emotions, mainly, as mentioned before, due to the preplanned policy of proselytism and hegemony pursued by Rome and its European allies in the $16^{\text {th }}$ century (but also earlier). In fact this policy was followed not only in India but also in the Middle East and almost in every region inhabited by a non-Roman Christian population. In this century Uniate Churches became to crop up. They were given various names referring more or less to their mother Churches. To realize the scale of this activity one should remember that European missionaries

${ }^{11}$ C. Buchanan, Christian Researches in Asia: with Notices of the Translation of the Scriptures into the Oriental Languages, $5^{\text {th }}$ ed., London: Printed by G. Sidney for T. Cadell and W. Davies, in the Strand 1812, pp. 106-108; A. S. Atiya, A History of Eastern Christianity, PAX, Warsaw 1978, p. 313; Mar Severios Ya'qūb Tūma, History of the Syriac Church in India, op. cit., p. 44. The authors quoted maintain it was Vasco da Gama who was said to have seen so many churches, which seems fairly unlikely as at that time the Portuguese did not feel safe enough in India to travel freely in the country.

${ }^{12}$ J. S. Assemanus (Assemani السمعاني), Bibliotheca Orientalis, Clementino-Vaticana, vol. 3, part I, Georg Olmus Verlag, Hildesheim-New York 1975, pp. 590-599. Without an access to the original it is difficult to guess in which of the three Syriac systems of writing the letter was written. This is probably why in all volumes of the Bibliotheca Assemani uses the Western font serto, used also by the Maronites since as a Maronite he was best acquainted with this font. Referring to an English version of the work by cardinal Eugène Tisserant, Eastern Christianity in India, London 1957, pp. 24-25, A. S. Atiya, A History of Eastern Christianity, op. cit., p. 312, notes that this unique document is deposited in the archives of Vatican (MS. Vat. Syr. 204) and that it was supposedly brought to Rome by A. Scander, a missionary working in the East in the years 1718-1721. From the information provided by A. S. Atiya it transpires that the letter had been perhaps written in the eastern font, which was erroneously called "Chaldean" by E. Tisserant. The Uniate community torn away from the Church of the East, called by the Vatican "the Chaldeans", was formed only dozens of years later. 
were as a rule backed by powerful European states. The Catholic kings of these states took more or less coordinated actions in line with the plan of the Roman popes, and their common aim was Latinization of Christianity at all cost. On the other hand, Christian communities in the East, which where the object of the missionary work, were stateless and usually lived under the yoke of the followers of other religions. This was one of the reasons why they where so happy to meet their fellow believers from Europe, hoping for their support, which is reflected also in the text of the following letter called by A. Mingana "a song sung by the Nestorian Church swans." The authors of the text were clergymen.

\section{The content of the letter and its translation}

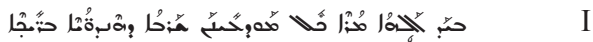

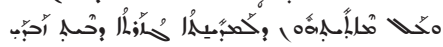

I With the help of God, the Lord of all and of everything, hereby we inform you of the story of honorable Indians and of their arrival to the city of Gāzarta belonging to Bēt Zabdāy. ${ }^{13}$

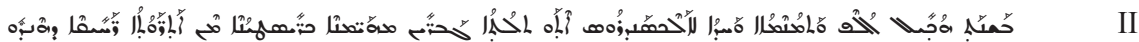

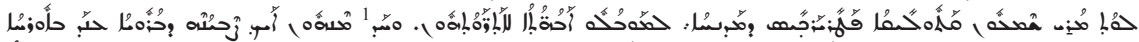

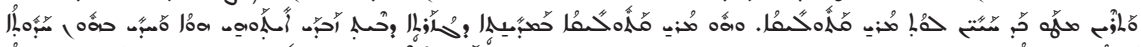

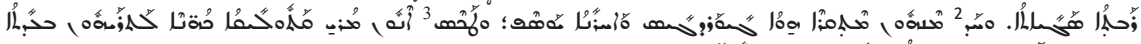

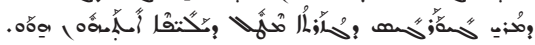
草

II In the year one thousand and one from the date of Alexander $[1489 / 1490]^{14}$ three men traveled from the distant lands of India to visit catholicos Mar Šem'un [V, 1497-1501], ${ }^{15}$ patriarch of the East. They were the rightful Christians and came to fetch clergymen to their lands. By the Creator's will one of them died on the way, and the other two reached Mar catholicos alive. And Mar catholicos resided in the town of Gāzarta which belonged to Bēt Zabdāy. He was greatly overjoyed to see them. One of the visitors was called Givwargis, and the other one - Yausef. ${ }^{16}$ Mar catholicos ordained both of them in Mar Gīwargis church in Gāzarta, as they were educated.

${ }^{13}$ Gāzarta, currently a small town in south-east Turkey on the Tigris river, by the Syrian-Iraqi border. Until the mid $19^{\text {th }}$ century both this town and other towns of the region Bêt Zabdāy had mainly Assyrian Christian population. Following numerous slaughter killings, the most tragic of which took place during World War I, they were almost completely replaced by the Kurds. Frequently dramatic situation of the Christians in the Middle East compelled patriarchs to leave their towns and to move to more quiet regions.

${ }^{14}$ Even not so long ago Syriac Churches used the date called the Alexandrian (after Alexander of Macedon), Greek or Seleucid date, where in all cases the starting date is usually the $1^{\text {st }}$ of October 312 BC, or more seldom 1st of April 311 BC.

${ }^{15}$ The chronology and the length of time in office of this patriarch and his two successors named in the letter were taken from Ch. Baumer, The Church of the East. An Illustrated History of Assyrian Church, op. cit., p. 318.

${ }^{16}$ This is the earlier mentioned Yausef, the priest who accompanied Cabral in his return trip to Europe. 


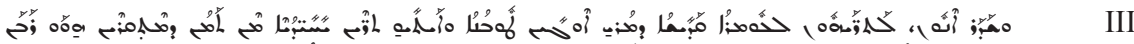

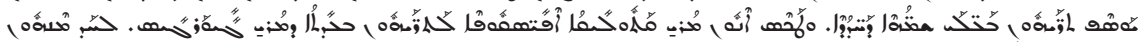

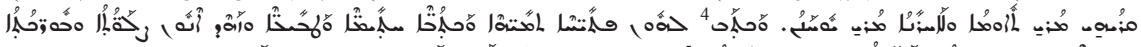

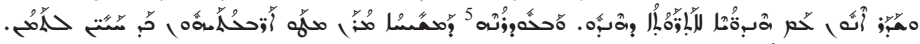
4

III And he sent both of them to the blessed Mar Augin Monastery. ${ }^{17}$ And from the monastery he fetched two hermits, both of them had the same name: Rabbān ${ }^{18}$ Yausef, and both of them Mar catholicos ordained for bishops in Mar Gīwargis' Church; he gave the name Mar Tūma to one of them, and Mar Yūhānon ${ }^{19}$ to the other one. He provided them with excellent letters of recommendation and with robustly bound books, he gave them his blessing and sent them with the said Indians to Indian lands. Owing the help of our Lord, Christ all four reached the destination alive.

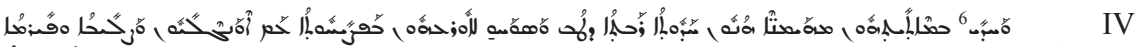

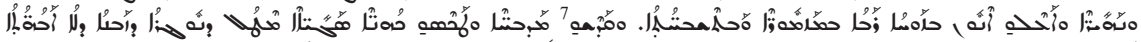

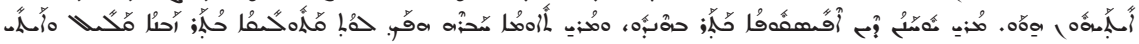

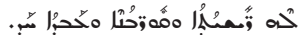

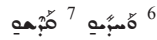

IV Those believers were very happy because of their arrival. A joyous greeting party carrying the Gospel, cross, censer and candles, singing Psalms and religious songs of grace set out to meet them and escorted them into the city. [The visitor clergymen] consecrated altars and ordained many priests, since [Christians in India] for a long time before that had had no clergymen. Bishop Mar Yūhānon stayed in India, while his companion, Mar Tūma, returned to the catholicos after a short time, taking letters and votive offerings for the catholicos and one servant with him.

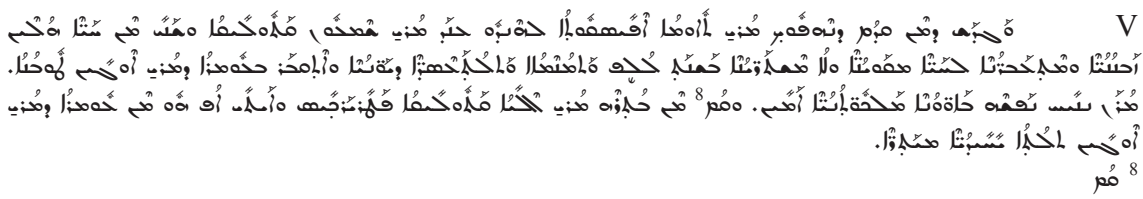

V So it happened that catholicos Mar Šem'un died before bishop Mar Tūma's return to India; he moved from this earthly and passing life to the eternal life, which is everlasting. This happened in the year one thousand eight hundred and thirteen according to the Greek calendar [1501/1502]. He was buried in the blessed Mar Augin Monastery. May our Lord bless his soul with peace in the royal chambers. Amen. His service as patriarch was then

${ }^{17}$ A monastery built at the turn of the $4^{\text {th }}$ and $5^{\text {th }}$ century on Mount Izla in Țūr 'Abdīn named after St. Eugene the Great, a Copt, who came to this part of Upper Mesopotamia along with many Egyptian monks. The monastery belonged alternately to the "Jacobites" and to the "Nestorians", depending on current political situation. Frequently attacked and devastated by the Kurds it was finally abandoned in 1970. Even if only few Assyrians remain in Țūr 'Abdīn, attempts are being made currently to reconstruct the monastery and return it to life.

${ }^{18}$ Rabbān, a honorary title conferred on educated monks or hermits. Its short version, rābī, is also used to refer to laymen enjoying authority and known for great knowledge.

${ }^{19}$ These are the names of Saint patrons. In Churches of Syriac tradition high rank clergymen (starting from bishop on) bear names of the patrons given to them during consecration ceremony, while their original names are always given as second in order. 
taken over by catholicos Mar Ēliyyo [V, 1502-1503]. He also brought [to his residence in Gāzarta] three meritorious hermits from Mar Augin Monastery.

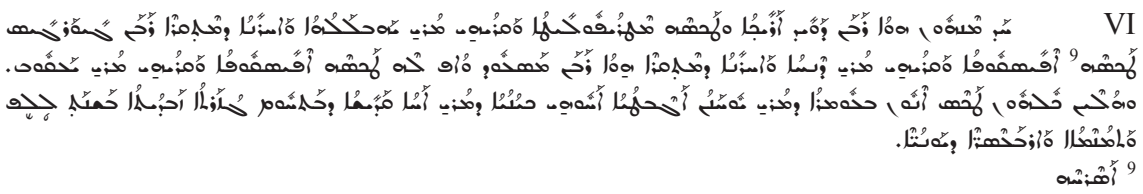

VI One of them was Rabbān Dāvid the Tall, whom he consecrated as metropolitan and gave the name of Mar Yā/h/bālāha. The second one was Rabbān Gīwargis, whom he consecrated as a bishop and gave the name of Mar Denho. And the third one was Rabbān Mas'ud who also was consecrated as bishop and given the name Mar Ya'qub. All three men were consecrated in the monastery of Mar Yūḥannon, a Copt, a biological brother of Saint Mar Āho, and the monastery is situated near Gāzarta d-Bẹt Zabdāi. ${ }^{20}$ This happened in the year one thousand eight hundred and fourteen according to the Greek calendar [1502/1503].

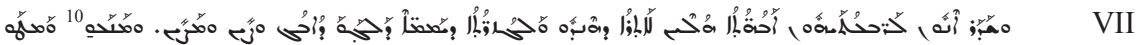

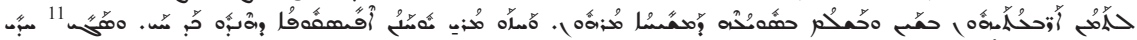

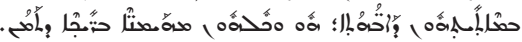

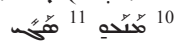

VII These four father confessors ${ }^{21}$ were sent by him to the state of India and to the sea islands in the region of Java ${ }^{22}$ as well as to China and Māșinn. ${ }^{23}$ Owing to the intercession of their Lord, Christ all four of them arrived there safely and in peace and saw there Mar Yūhānon, the bishop of India, as he was still alive at that time. Both the bishop himself and all of the blessed local believers were very glad of their arrival.

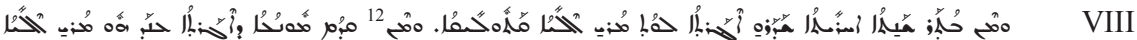

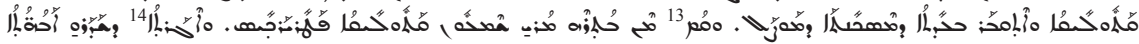

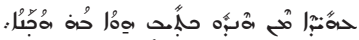

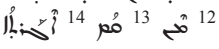

VIII After a year they dispatched a letter to catholicos Mar Ēliyyo. But before the letter was delivered catholicos Mar Ëliyyo died and was buried in the church of Mart Meskinta in Mosul. ${ }^{24} \mathrm{He}$ was succeeded by catholicos Mar Šem 'un, patriarch. The letter the aforementioned father confessors dispatched from India read as follows:

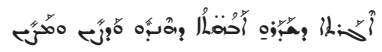

IX The content of the letter sent by father confessors of India, China and Māṣīn was as follows:

${ }^{20}$ From the name Bēt Zabdāi.

${ }^{21}$ Mar Tüma was the fourth one.

${ }^{22}$ Due to lack of this entry in available dictionaries I used a translation given in A. Mingana, The Early Spread of Christianity in India, op. cit., p. 51.

${ }^{23}$ This name can be found in no dictionaries and it was omitted in earlier translations, also in Assemani. The only reference to a land bearing the name recorded in the Māğin version can be found in the book by I. Armala, تاريخ الكنيسة السريانية History of the Syriac Church, Beth Zabdai-Azech, Beirut 1996, p. 343, who mentioned it as one of dioceses of the Church of the East in the $14^{\text {th }} \mathrm{c}$. in south China, with the city of Nankin (?) supposedly being its main city. However in page 370 he writes that the name Māğīn was synonymous with the name Atil. See footnote 31 .

${ }^{24}$ Clergymen tend to be buried in crypts, usually in a separate cellar room beneath the church altar. St. Meskinta (currently Maskanta) Church in Mosul is owned by the Chaldean Church. 


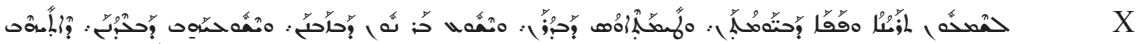

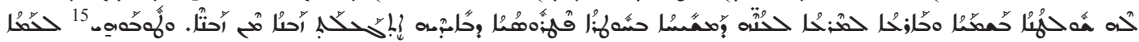

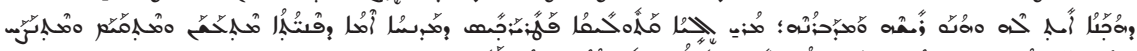

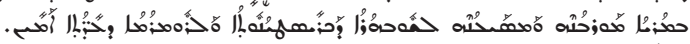

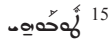

X To Šem 'un II [VI, 1504-1538], ${ }^{25}$ the Pope of our days, ${ }^{26}{ }^{26}$ Ṭimāteus of our era, ${ }^{27}$ Yēšŭ bār Nūn of our times, ${ }^{28} \mathrm{Y} \bar{e} \bar{u}^{\mathrm{u}} \mathrm{y} / \mathrm{a} / \mathrm{h} / \mathrm{b}$ of our seasons, ${ }^{29}$ who was given power in heaven and on earth, to shepherd the Christ's sheep with Peter's staff which he has inherited for the time which is destined for him. Enviable is the people that has such a leader and that is headed and lead by such a leader, [and this leader is] Mar Ëliyyo, catholicos, patriarch of the East, which is the mother of all cardinal directions. May he be strengthened, may he triumph and be glorified in Lord, who is his support and who elevates him for the glory of the Christianity and in order to elevate the dignity of the Church. Amen.

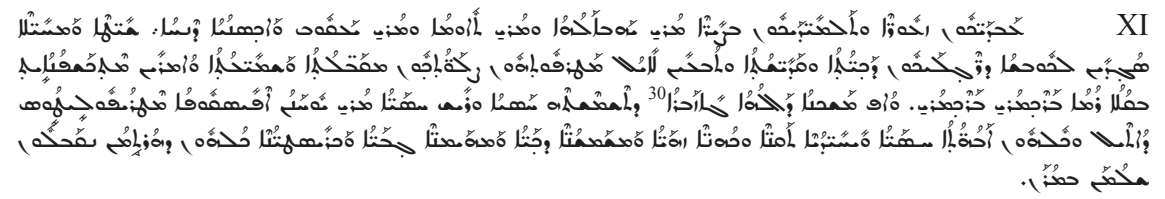

XI Your insignificant and imperfect, undeserving and humble servants: Mar Yābālāha, Mar Tūma, Mar Ya'qub and Denḥa Ahesnāya, are bowing to your feet and ask for your support in your answered prayers, since they falter and are weak and with humiliation they plead loudly: Bless us, Lord, Bless us, Lord. May the sign of peace be accepted by: bishop metropolitan Atil ${ }^{13}$ Mar Yūhānon, who is an altar of God and a guard in His service, all bishop fathers,

${ }^{25}$ Unlike the two former patriarchs, Simeon VI resided in Rabban Hormizd monastery, close to the Iraqi city of Mosul.

${ }^{26}$ Pappa is the Syriac version. As opposed to the Coptic patriarchs of Alexandria referred to as popes, patriarchs of the Syriac Churches (Church of Antioch and of Seleucia - Ctesiphon) did not use this title.

${ }^{27}$ There were two Timothys (Țīmāteus) that held the throne of the Patriarch of the Church of the East: Timothy I the Great (780-823) and Timothy II (1318-1332). Activity of the first one was discussed extensively by A. Abūna, تاريخ الكنيسة السريانبة الثرقية History of the Syriac Church of the East, Dār al-Mašriq, Beirut 1993, vol. 2, pp. 113-145. He was born in the village of Hazza situated south-west of the modern city of Irbil in north Iraq. The place of birth of the other patriarch is unknown, but we know that he lived in a period that witnessed upheavals and many massacres of the Assyrian population perpetrated by Muslims. He died in Irbil.

${ }^{28} 823-827$. Successor of Timothy the Great. He was born in the village of Bēt Gabbāre near Mosul.

${ }^{29}$ In the Church of the East there were a number of patriarchs bearing this name: Yēšū ${ }^{6} \mathrm{a} / \mathrm{h} / \mathrm{b}$ I (581-595), Yēšū ‘yā/h/b II (628-644), Yēšū'yā/h/b III (649-659), Yēšū ‘yā/h/b IV (1021-1025) and Yěšu' 'yā/h/b V (1149-1175). The meaning of the name is "given by Jesus."

${ }^{30}$ In R. P. Smith's dictionary, A Compendious Syriac Dictionary, Winona Lake, Indiana: Eisenbrauns 1998, it is given in the form ${ }^{2}$

${ }^{31}$ Among the 36 dioceses of the Church of the East strictly within the area of Persia an in the Indian Ocean region listed by A. Mingana, The Early Spread of Christianity in India, op. cit., pp. 76-86, there is no diocese bearing a name resembling this one. It cannot be excluded this may refer to the city of Atil, situated north-west of the Caspian Sea, which was allegedly destroyed in the $10^{\text {th }}$ century but A. Abūna mentions it twice in his work History of the Syriac Church of the 
hermits obedient to God, noble priests, ministers with pure hearts, unfaltering believers and all the Christians in Your parts.

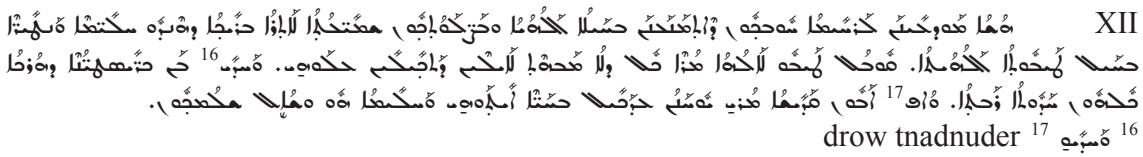

XII And now we are informing Your Grace that owing to the power of God and to Your prayers we have reached the blessed state of India in good health and shielded with the power of God's favors. We are grateful to God, the Lord of all and everything. Those who rely on Him, shall not be disappointed. All local Christians were very happy and with them our father, Saint Mar Yūhānon, who is still alive, in good health and sends his greetings to You.

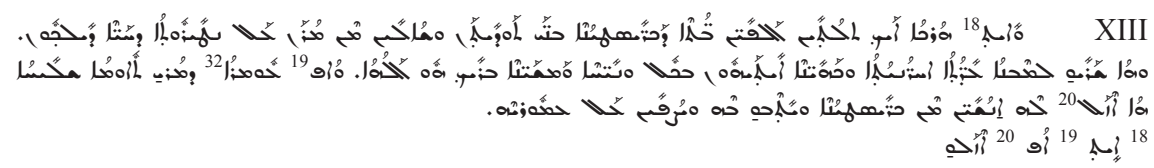

XIII Here we have around thirty thousand Christian families, ${ }^{33}$ our fellow believers. They ask God to protect You. Already they have started building new churches. Thank God, they are ingenious in everything, quiet and peace-loving people. A group of Christians have traveled also to Mar Tūma's Monastery. They live there and take care of its refurbishment.

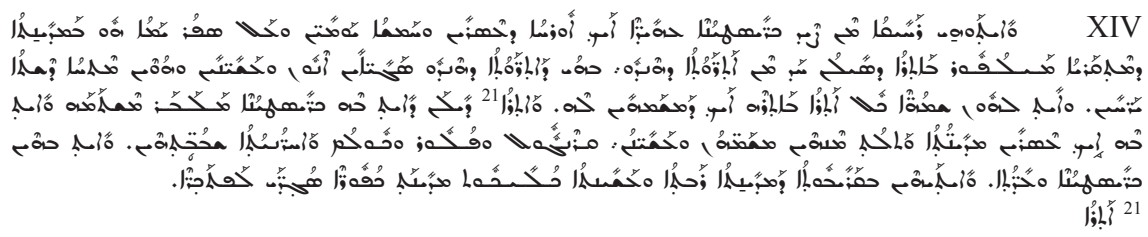

官遂 21

XIV The monastery is situated at a distance of some twenty five days' travel by foot from the place where these Christians reside. It lies at the coast in city called Majlappur, in the land of Ceylon, ${ }^{34}$ one of plenty in India. Indian lands are powerful and it takes almost six months to reach them. Each of them has its name. Our land, where Christians live is called Malabar. There are some twenty cities there, and three of them Kranganor, Pallor and Kollam are famous and powerful. There are also others, neighboring with them, with Christians and churches. They are situated at a small distance from big and powerful Culicut, the city of pagans who worship idols.

East, op. cit., vol. 3.,pp. 99, 188, as the capital of the Empire of Cathay and as a place from which the family the would-be Syriac writer named Ataya bar Abda (d. 1562) emigrated to Gāzarta at the beginning of the $15^{\text {th }}$ century. I. Armala, History of the Syriac Church, op. cit., p. 370, writes that at the beginning of the $16^{\text {th }} \mathrm{c}$. Atil (vel Māğin) still was a diocese of the Church of the East and its archbishop was Mar Yūhānon.

32 خَم "umro means both a monastery and a chapel in which one or two monks reside.

${ }^{33}$ That is ca. 150-200 thousand people. It is worth noting that probably due to lack of accuracy some Syriac sources quote the number of 30 thousand people, while other -300 thousand.

${ }^{34}$ Numerous Syriac writers, especially western ones, including those who lived in the $13^{\text {th }}$ century, when referring to Indians usually meant the Ethiopians and/or Arab Himyarites. Some of them distinguished Great, Internal, Central, North, and External India and even included the city of Kabul as part of India, while others not only treated Ceylon as part of India but also called the island India Proper. 


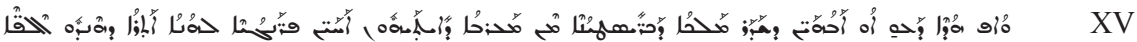

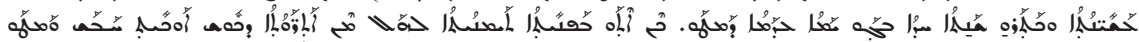

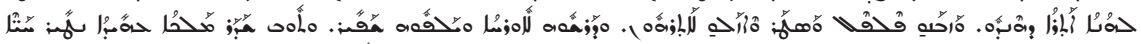

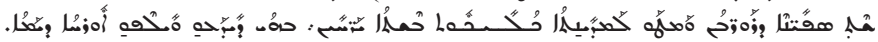

XV You should also know, our Fathers, that the King of the Christians from the West, these being our brothers, the Franks, ${ }^{35}$ had sent powerful ships to the state of India. They were sailing for one year before they reached our land. ${ }^{36}$ They arrived to India from the south, from the lands of Kush, that is Habaš. ${ }^{37}$ They purchased pepper and the like and returned to their country. They tested the route and mastered it well. Later the said King, may his life be secure, sent out six huge ships that reached the city of Calicut within six months, as they learnt the sea route before and mastered it well.

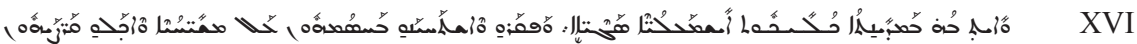

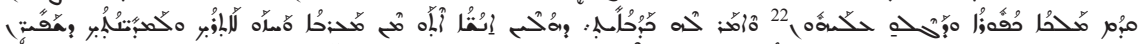

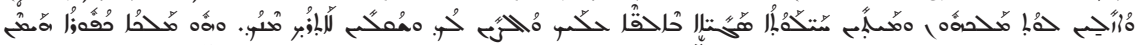

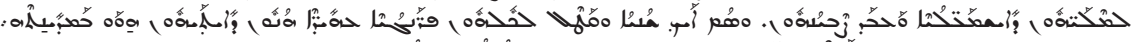

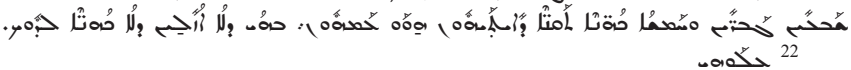

XVI In the city of Calicut there are many Ishmaelites. ${ }^{38}$ Envy towards the Christians infuriated and enraged them, that is why they slanderously accused the Christians before the pagan Raja telling him untruthfully: "These people came from the West and saw that your country and your cities are beautiful. They will return to their king and bring many troops on ships in order to put pressure on you and to take over your country." This pagan Raja believed in the words of the Ishmaelites and did as they wanted him to do. Like insane he killed all the Franks in his city, the number of whom was seventy four together with five venerable priests who accompanied them, as they never go anywhere without priests.

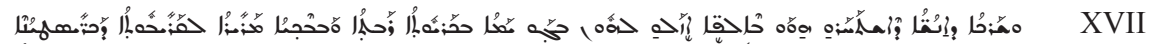

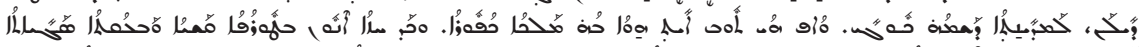

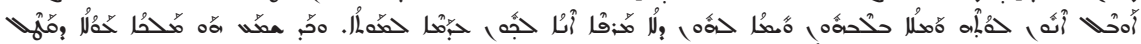

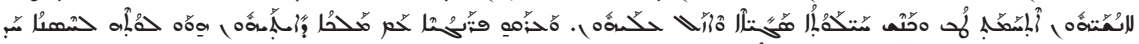

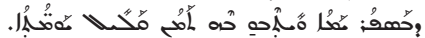

XVII The other people [Franks], who stayed on the ships sailed away to the sea in great sadness and grief and lamenting they came close to our Christians to the city called Cochi (Cochin). The Raja of this city was also pagan but when he saw they were extremely exhausted and that their situation was hopeless, he brought them to his place, consoled them and swore that he would not leave them until death. When the villain Raja [of Calicut] who had killed their companions learned about that, he became furious, gathered great forces and attacked them. Together with the Raja who was their host the Franks fled to a castle on the sea coast and stayed there for a few days.

${ }^{35}$ In the Syriac text: وصتّنُ Frangōye.

${ }^{36}$ Vasco da Gama's sea voyage lasted from 8 July 1497 to 20 May 1498, that is ten and a half months.

${ }^{37}$ بحَحم Habaš (synonym for Ethiopia) - this name used in the Syriac and Arabic language derives from South Arabic and denotes a person of mixed ethnic origin.

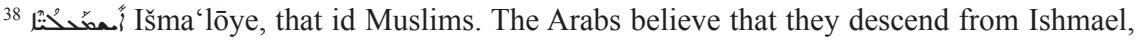
Abraham's son. In Syriac literature Arabs are often referred to also as the Hagars, from Ishmael's mother's name, Hagar. 


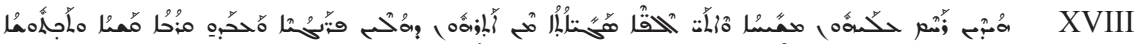

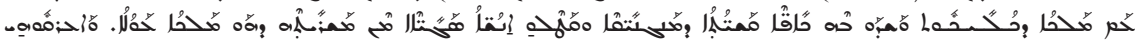

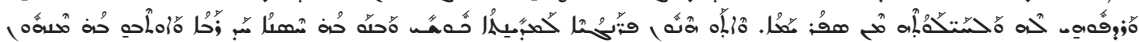

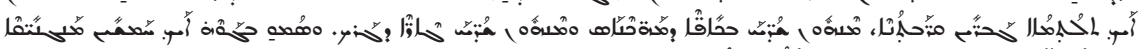

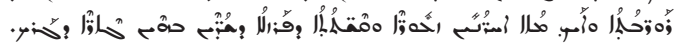

XVIII Then Christ had pity on them; many ships sailed from the country of the Franks and a great battle was fought with the Raja of Calicut: catapults were used to eject hard stones and many people of the villain Raja were killed and the Raja and his troops were chased away from the coast. [Next] the Franks arrived to the city of Cochin and built a powerful castle where they deployed almost three hundred warriors; there were men throwing stones with bombards and crossbow shooters among them. [Apart from that] they armed the castle with almost fifty huge catapults and a hundred of small ones, as well as iron bows used to shoot crossbow arrows.

$$
\begin{aligned}
& \text { 望 } \\
& { }^{24}
\end{aligned}
$$

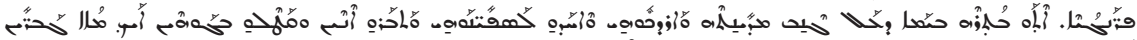

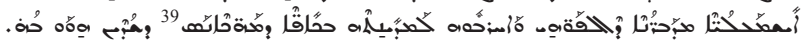

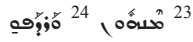

XIX Their enemy, the Raja with fallible memory attacked them again and fought a battle with them, but they defeated him with Christ's power and killed almost three thousand of his men with catapulted stones. Again the Raja fled to his city of Calicut and persecuted the Franks [who lived there]. [However the Franks] set out after him from the sea, tracked him down, stopped his ships, destroyed them and killed almost one hundred of the Ishmaelite crew on board and then destroyed his city with stones shot from the bombards they brought with them.

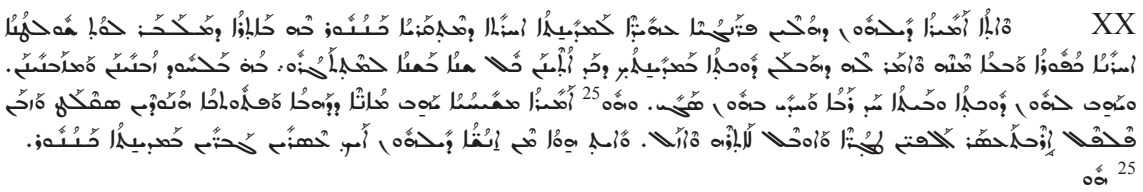

XX The commander in chief of the said Franks then headed to another city, named Kannanur in Malabar, to meet another pagan raja. He pleaded with him: "Give us a place in your city so that we can trade year after year; and we will buy and sell only in this place." The Raja gave them the place and a big house and was very delighted. The Christian commander then gave [to that Raja] objects made of gold and other ornaments as well as the purple, and later purchased fourteen thousand țgore ${ }^{40}$ of pepper, which he took to his country, leaving around twenty of his people in Kannanur.

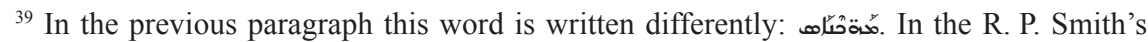

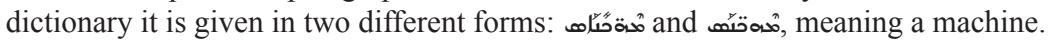

${ }^{40}$ A unit of weight. A. Mingana, The Early Spread of Christianity in India, op. cit., p. 54, notes that one tughar used to be an equivalent of almost $200 \mathrm{~kg}$, however according to available scales and conversions tughar was or is an equivalent of $2,032 \mathrm{~kg}$. If we take the value given by A. Mingana as correct, this would mean that the quantity of the purchased pepper was 2800 tons, which seems to be a very unlikely amount. The other conversion results in the quantity of 28.5 tons. In his monumental work, Francis Buchanan, A Journey from Madras through the Countries of Mysore, Canara, and Malabar, 1807, no place of publication given, p. 354, mentions no such unit of weight. Reprints of the book: Asian Educational Services, India, 1996, 


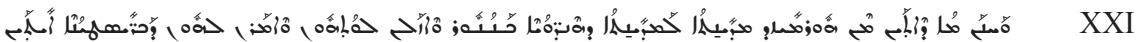

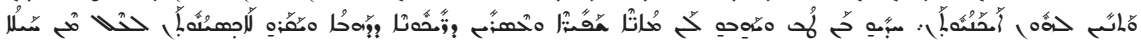

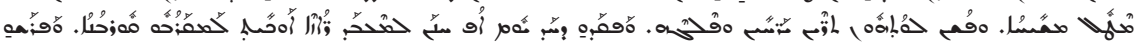

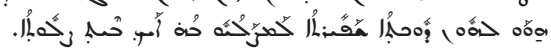

XXI And on arrival from the city of Hormizd ${ }^{41}$ to the Indian city of Kannanur we went to see them and told them that we are Christians and described our situation. They rejoiced at this greatly, gave us nice clothes and twenty gold darics. ${ }^{42}$ And because we are strangers they showed us respect, for Christ. We stayed at their house for two and a half months. One day they asked us to celebrate the sacrament, that is the Holy Mass. At the same time they marked out a nice place which was used by them as a house of prayer.

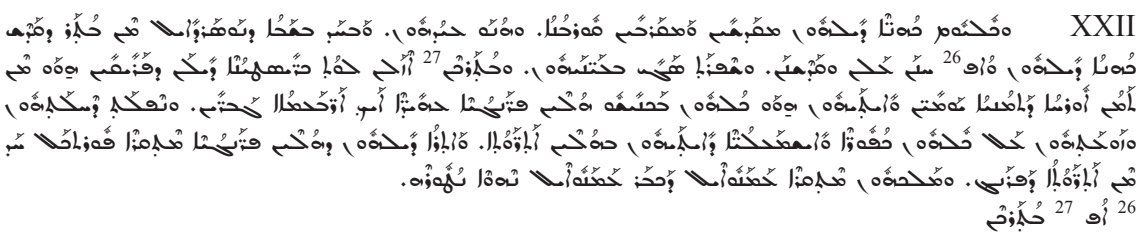

XXII Their priests celebrate a liturgy every day. Such is their custom. On Nausardil ${ }^{43}$ Sunday, after the liturgy celebrated by their priest also we entered and celebrated out service. They were pleased with it very much. Later on we traveled to see our Christians whose place was eight days' travel away. All these Franks were a group of almost four hundred strong, but they were a terror of all the pagans and Ishmaelites who live in these countries. The land of these Franks is called Purtkal (Portugal) and is one of the Frank countries. Their king's name is Emmanuel, may Emmanuel ${ }^{44}$ protect him.

pp. 1469; Cambridge University Press, 2011, one volume, pp. 1688 and in three volumes - pp. 482,590 and 630.

${ }^{41}$ It is probably a reference to a city in Iranian Khuzestan (currently Al-Ahwāz), which as early as in the year 225 was an Episcopal see of the Church of the East established in the diocese named Hormizd-Ardashir. The name of the first bishop residing there mentioned in Syriac sources was Yūhānon. He died a martyr's death in 341. See A. Mingana, The Early Spread of Christianity in India, op. cit., p. 78.

${ }^{42}$ A Persian gold coin named from Darius Hystaspes who stuck them. It is worth about a guinea. R. P. Smith, A Compendious Syriac Dictionary, op. cit., p. 97.

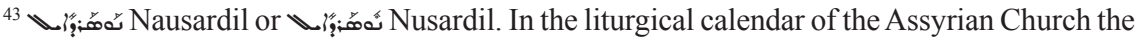

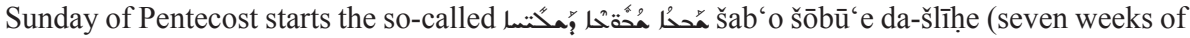
the Apostles) period, and on its lapse, that is after 49 days comes Nausardil Sunday, starting the seven-Sunday long summer period. It is very likely that Nausardil is a heterogeneous Persian and Syriac word: nausar (from Persian nauua - "new" and sared - "year") and \i, d-îl, which could translate as "God's feast." On this Sunday, celebrated as the Sunday of penance, the Assyrians keep pouring water on one another during the whole day. In popular beliefs the ceremony is said to refer to the adoption of Christianity on a mass scale, as symbolized by baptism, or to giving up of the cult of fire by extinguishing of this element with water. The word itself denotes also unripe dates. See the entry in the dictionary: M. Sokoloff, A Syriac Lexicon. A Translation from the Latin, Correction, Expansion, and Update of C. Brockelmann's Lexicon Syriacum, Co-published by Eisenbrauns and Gorgias Press, 2009.

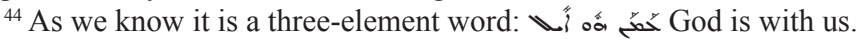




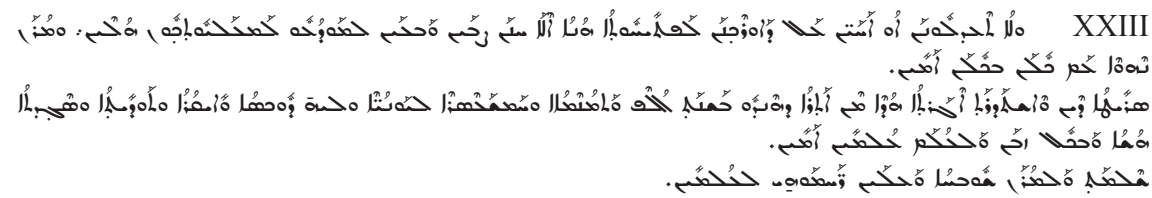

XXIII Brothers, do not hold it against us that we have made this letter so long. We want Your Excellencies to know [what we have found here]. May our Lord be with us all and in us. Amen.

This letter was written and dispatched from the state of India in the year one thousand eight hundred and fifteen according to the Greek calendar [1503/1504]. Glory to the Lord, respect, gratefulness and a bow before You, now and at any time and for ever and ever. Amen.

The end. Glory to Our Lord and His eternal favors He grants us.

\section{Commentary}

The authenticity of the presented letter is unquestionable. It has been confirmed both by Syriac sources, including the Uniate ones, ${ }^{45}$ which makes it the more important and credible, and by European and American sources. It is worth noting that the confessional affiliation (Protestant, Anglican or other) of the foreign authors of these works seems to be an issue of secondary importance for them. It does not prevent them from seeing things as they are and from presenting the true picture of historical events. They present the same critical distance to the practices of the Syriac Christians in India, seeing them as controversial from their point of view, to the mechanism of functioning of that Church before the arrival of the well-organized Europeans, and to the proselytism of the Catholic, mainly Jesuit, but also Protestant missionaries who arrived to India with the Dutch, and later also of Anglican missionaries. The Malabar Christians found themselves in a difficult situation when confronted with European missions. The missions had support of powerful and rich Church institutions and were equipped with state power instruments. They were backed by powerful occupying states, considerable military power and a budget appropriated specifically for their activity. No wonder they attempted to win over and assimilate possibly the largest numbers of local Christians and to make them join their sheepfold. They were expected to achieve that. The most drastic methods and the most devastating results are ascribed to the Portuguese and their missionaries. Their practices towards the local Christians included jailing, the Holy Inquisition Tribunal sentences, burning at stakes and burning of books as well as blocking the visits of priests from Mesopotamia. In order to legalize proselytism they branded these Christians as "heretics" or "the unbaptized", the first accusation being of relative nature,

${ }^{45}$ See for instance A. Abūna, History of the Syriac Church of the East, op. cit., vol. 3, pp. 96-100; I. Armala, History of the Syriac Church, op. cit., pp. 370, 391. 
and those who use it today are not in the least right, while the other one being completely untrue - this issue deserves a separate publication.

Shorter or longer fragments of the above letter can be found in many works; some of them are quoted in the relevant footnotes. As mentioned before, the whole text of the letter was quoted by Assemani, a Maronite, i.e., a Uniate author, in his historic work Bibliotheca Orientalis, thought to be probably the earliest or one of the earliest in Europe complementary works devoted to Syriac literature. And it is perhaps only owing to this fact that the letter has not shared the fate of other documents of the Indian Church thrown into fire on orders of Alexis de Menezes, Jesuit Archbishop of Goa, after the Synod of Diamper (1599), because it was sent to Mesopotamia, where it was then stored in the Church archives only later to be transferred to Europe during a big scale operation of buying out, or simply stealing, of manuscripts. It is also possible that the letter (or its copy) could be one of few texts that did not fall into the hands of Alexis de Menezes in India, since, like the other few books, it was a part of one of the Indian hierarchs' private collection of books. To make the picture complete it is worth mentioning that acquiring of Syriac books, and at any cost too, was practiced not only by the Roman Catholic missionaries or the won-over Uniates, as Assemani (1687-1768) himself, who were sent to the Middle East for this very purpose for instance from the Maronite College opened in Rome in 1584, but also by the Anglicans. Such trade was observed in every place which the missionaries were able to reach. ${ }^{46}$ This explains why so many more Syriac manuscripts can be found in the Vatican library and in different book collections in other European countries with the colonial past (though not only) and in the USA, than in India or in the Middle East.

The structure of letter includes two parts. In the first part the following facts are worth noting:

\footnotetext{
${ }^{46}$ Hunting for "heretic" books in monasteries in Lebanon and their destruction by burning by Jesuit Giovanni Battista Eliano in the years 1578-1580 is described for instance by authors such as I. Armala, History of the Syriac Church, op. cit., p. 204; M. Moosa, The Maronites in History, Gorgias Press, 2005 (2nd ed.), pp. 245-252; Ph. Terrazi, أصدق ما كان عن تاريخ لبنان وصفحة من أخبار السريان The Most true history of Lebanon and a page from the book of knowledge about the Assyrians, vol. I, Beirut 1948, pp. 94-100, 146-148. Burning of books with time replaced with less drastic methods such as deletion or amending of the text to make it conforming with the doctrine of the Roman Catholic Church was in fact an implementation of the decrees adopted at the Council of Trent (1545-1563), which according to the decisions taken there were planned to be used not only in the Roman Catholic church but also beyond it, all over the world. These and other "regulations" introduced at the times of Popes Pius IV and Paul IV remained valid for over 300 years. See H. Tüchle, C. A. Bouman, Historia Kościoła, op. cit., p. 130. A list of seventeen manuscripts stored in Vatican, with visible marks of deletion and amendment with titles and information on their contents, A. Mingana, The Early Spread of Christianity in India, op. cit., pp. 89-92. Also it needs to be reminded that, e.g., in south-east Turkey and in north Iraq, European missionaries often bribed the local Kurds to obtain for them manuscripts from the Assyrian monasteries by force.
} 
- The visitors from India were indigenous Indians, but they bore typical Syriac names that are popular in the Middle East and without any doubt represented the multitude of the local believers. This is evident from the way they were farewelled on departure and greeted on return, which was the same as the ceremonies practiced in Mesopotamia. Thus, it can be said, that also in terms of the names chosen and religious folklore the Christian Indians to a certain degree adopted and cultivated the Middle East patterns.

- The recognition of the primacy of the patriarch of the Church of Mesopotamia. He consecrated successive bishops and sent them to India, regardless of whether they were native Indians or Assyrians. The hierarchy of the Church in India included both the former and the latter all the time. Hardships and dangers associated with months-long journey did not prevent them from keeping in contact. This was all the more troublesome and even discouraging, as the residence of the patriarch in Mesopotamia was not stationary but was often moved from one place to another depending on a political situation at a given time, but was always the centre. The patriarch's apostolic letters to the followers in India as well as the letters he received from the country, and the mutual exchange of gifts by the parties reflect the fact of the recognition of his jurisdiction and great respect that his office enjoyed among the believers.

- The fact that the Authors of the letter just refer to themselves as Christians, putting no emphasis on the name of the Church they are presenting indicates that at that time there were no divisions in the Christian community of India. A succession of schisms took place after the Portuguese and later the Dutch and English influences had strengthened. The new Latin rite, Uniate, Protestant, Anglican and other Churches started to emerge. The history of the Church in India may actually be split into two periods: before and after the Synod of Diamper.

In the other part of the letter the following elements are evident:

- The hierarchs in India are proud of their patriarch. Aware of the history and contribution of their Church they compare the present patriarch to his most eminent predecessors. They are also convinced that he is St. Peter's deputy and the fact that they refer to him as to "the Pope of our days" may suggest, that they already had some contacts with the Portuguese from whom they could have heard that the only true shepherd resides elsewhere, in the West, with which they surely disagreed. Also in this part of the letter the authors refer to Christianity in general and not to the particular Church they belong to. It is evident that at that time they had no sense whatsoever of the lurking proselytism which they had not known before, and of the imminent break up of their Church.

- Valuable mentions on the size of the Christian community, its good condition and on the erection of new churches and information that the "monastery" of St. Thomas is under reconstruction - these data give grounds for a conclusion that the Church in India was growing. The concise information to the effect 
that both the old and new churches are taken care of by Christians, does not necessarily mean that these Christians were Portuguese, although we know that the first individual Roman Catholic missionaries arrived to visit St. Thomas' grave as early as at the end of the $13^{\text {th }}$ century.

- Geographical data on the Indian territory and on Indian state, especially on Malabar region and its most important cities and information on distances or the length of the Indian borders, measured in days or months (of travel by foot) was probably provided to the authors on their arrival. This is also true of the route and duration of the Portuguese fleet's voyage. Although the arrival of the Portuguese must have been an important event, there is no mention of Africa, and no information on the order of the see voyages in the letter. Neither the name of Vasco da Gama nor of P. A. Cabral appears in it. The description is fairly general; for instance, the number of six ships taking part in the first voyage is incorrect as the first expedition involved four ships, the second - thirteen and the third one - twenty ships. The information about the killing of the seventy Portuguese sailors and five priests in Calicut indicates, that the authors refer to the second expedition (the first crew commanded by Vasco da Gama was 160-170 strong, and the crew commanded by P. A. Cabral - counted over one thousand people). If we are to believe the authors of the letter the attack was inspired by Muslims from Calicut, who managed to convince the Raja, referred to as "pagan", that the Portuguese may turn out to be occupants. Upset with the death of their companions the Portuguese looked for shelter at Syriac Christians' quarters in Cochin. And in spite of being "pagan" too the local Raja offered them protection, for which he had to pay a price, as he was forced to escape from the city along with the Portuguese. Thus can we presume that Christians of Cochin were a significant community and that the lives of the visitors from Europe were saved owing to their intervention? The letter does not mention whether the local Christians were also attacked by the Raja of Calicut.

- The use of force by the Portuguese, who arrived by sea to the relief of their compatriots and defeated the Raja of Calicut. Their good relations with the Raja of Cochin resulted in building of a castle in the city. The fortress was equipped with military equipment such as bombards, ballistae, catapults, and iron bows, brought from Portugal, and was manned with experienced soldiers. The Portuguese fleet must have been powerful; probably this refers to the second expedition of Vasco da Gama. However the Raja of Calicut did not accept the defeat he had suffered and launched another unsuccessful attack on the Portuguese, which cost him thousands of dead troops and destruction of his fleet including the death of the Muslim crew. Another important aspect should be noted: already at this stage of the Portuguese presence a local political conflict and military confrontation between the rajas of Calicut and Cochin took place. 
- This victory must have inspired fear in the region and surely did help the Portuguese in starting commercial relations with other cities on the Malabar coast, for instance, they bought large quantities of pepper in Kannanur and although the raja of this city also was "pagan" he offered them a location and a large building where they established a trading post. Perhaps he did this because he felt he had no choice or he believed in the assurances of the Portuguese that they were interested only in trading.

- The visit of the authors of the letter at the Portuguese post in the city of Kannanur. The meeting must have been pleasant for both sides if the members of the delegation were hosted there for over two months. They participated in daily liturgies celebrated by Portuguese priests and only once they were asked to celebrate liturgy according to the Syriac rite. This happened on the eight Sunday after Pentecost, that is at the turn of July and August 1503 or 1504. Referring to this Sunday as Nausardil, or Nusardil, proves Syriac influences on the liturgical calendar of the Church.

- The return of the delegation to their Syriac Christian community. In the letter we only find information that the return journey lasted eight days. No destination name is given, however it cannot be excluded that it was Cochin, where - as mentioned before - relatively many Portuguese stayed. The fact that the delegation successfully reached the destination indicates that they had a safe journey. Presumably, despite being the followers of the same religion as the Portuguese the local Christians did not become an object of revenge by the Malabar Muslims gripped by a great fear of the powerful Europeans.

- The closing of the letter with a plea to the heavenly Emmanuel to protect the earthly Emmanuel, the king of the Portuguese.

\section{Summing up}

The information presented in the above quoted letter in numerous aspects confirms information given in many other sources on the Church in India, though discrepancies are evident in many other aspects. The conformities include depiction of Portuguese's vigorous efforts to enter spice trade with India as well as the fact that they had met with rather cool reception from Malabar rajas. The reason for such attitude could be the fact that not all the local rajas believed in peaceful intentions of the visitors arriving from distant lands on a well armed fleet of ships, which eventually resulted in serious clashes between them, although a religious factor of the animosities cannot be altogether excluded. The main contentious matters, on the other hand, setting aside immaterial details, included undoubtedly the absence in the available version of this letter of the Fathers of the Syriac Church in India of any mention whatsoever on the subjects of the talks they held with the Portuguese. This is totally incomprehensible, especially in the 
light of the fact that they were their guests for over two months. What I mean, are quoted above, let us call them, "threats" voiced by the Portuguese that the Syrian churches in India shall belong to the Pope. A question may be asked at this point: Was this fragment, if it indeed was a part of the letter, intentionally omitted by Assemani in his book? Assemani was a follower of the Church of Lebanon annexed by Rome and was active in the Maronite College established in Rome, to which talented Lebanese Uniates were brought, especially those devoted to papacy. All the sources that mention the contemplated letter refer to its version published by Assemani. Thus it may be presumed that Assemani could have been the first to get hold of the document, for instance through one of the hierarchs from a group separated from the ancient Church of Mesopotamia, named Chaldeans by the Pope. ${ }^{47}$ The document could have been kept in the earlier mentioned Rabban Hormizd monastery, which after the schism in the Church of Mesopotamia in the mid $16^{\text {th }}$ century became the possession of the Chaldean group. The patriarch, who was the addressee of the letter, resided in it. Rabban Hormizd was also a home monastery of monk Sulaqa ordained on the $20^{\text {th }}$ of February 1553 in Rome by Pope Julius III the first patriarch of the Uniate (Chaldean) Church in Mesopotamia.

There is nothing to indicate in the letter that the successors of its authors will become so much disillusioned after a time shorter than one century from the events they describe; their authentic joy on the arrival of their brothers from distant Europe eventually turned into a struggle to survive and to preserve their identity. As mentioned before, the intention of the Portuguese visitors was to cut the Malabar Christians away from their roots and to achieve this they took great efforts to block the flow of clergymen from Mesopotamia to India. Those who managed to come were treated in an extremely harsh manner. The Portuguese even went as far as to put obstacles to the entry of other Catholic, non-Portuguese clergymen to the area under their control. Therefore it is understandable that implementing the plan of complete Latinization of the local Christians, they had a rather unfriendly attitude towards the hierarchs from Mesopotamia, who had become the Uniates only recently. Bishop Yausef, a brother of the earlier mentioned patriarch Sulaqa, when deported from India even went to Rome to

\footnotetext{
${ }^{47}$ This hypothesis can be corroborated for instance by the fact that the writing in which the letter had been written was referred to as Chaldean an not Syriac, as noted instance by a Uniate Syriac bishop, A. A. Abūna in his work History of the Syriac Church of the East, op. cit., vol. 3, p. 100. I. Armala, History of the Syriac Church, op. cit., p. 369, who wrote: "Pope Eugene IV (1431-1447) in his bulla of 7 July 1445 announced that the Assyrians who have joined the Roman Church in Cyprus should be called Chaldeans. The name, however, became common only 150 years later, during the time in office of the Chaldean patriarch Joseph I (1681-1707). Up to that time they were referred to by a two component word: ChaldoAssyrians. To be exact one should add that those of them who live in villages near Mosul still call themselves the Assyrians."
} 
complain to the Pope about it. ${ }^{48} \mathrm{~A}$ true manifestation of the real lack of respect and understanding for the history and tradition of the local Christians was observed at the Synod of Diamper (1599), in the non-Catholic literature referred to as the "synod of thieves," 49 and the Catholic sources described as follows: "Christians of St. Thomas entered into a union with Rome. Their unique rite was looked at askance. Attempts to subjugate them to the Latin rite lead to partial breakup of the union." 50

${ }^{48}$ Syriac bishop Atalla had even less luck. He was sent to India by Coptic patriarch of Alexandria probably in order to outwit the Portuguese. "In 1652 he arrived to Surat, from where he headed for Majlappur. The news about his arrival electrified the local community, but the Jesuits arrested him quickly. He was sent back to Goa, and brought before the Holy Inquisition tribunal and burnt at the stake in 1654 as a heretic." A. S. Atiya, A History of Eastern Christianity, op. cit., p. 314.

${ }^{49}$ To find out about these deserving severe condemnation endeavors of Alexis de Menezes in the period preceding the synod and about the participants and the canons of the synod see for instance Mar Severios Ya'qūb Tūma, History of the Syriac Church in India, op. cit., pp. 52-62. The quoted author, a later patriarch of the Syrian orthodox Church of Antioch (Ignatius Jacob III, 1957-1980) refers to the period before the Synod of Diamper as the first wave of persecution, and the period after this synod, as the second wave of persecution.

${ }^{50}$ H. Tüchle, C. A. Bouman, Historia Kościoła, vol. 3., op. cit., p. 200. The $16^{\text {th }}$ century history of the Roman Church, described in this five-volume work, translated into the Polish language without commentary, leaves no doubt that Rome actually did not regard Christians of other than Roman Catholic rites as Christians. 